\title{
Why busways? Styles of planning and mode-choice decision-making in Brisbane's transport networks
}

\section{Michael Tanko \& Matthew Burke}

Tocite this artic le: M ichaelTanko \& Matthew Burke (2015) Why busways? Styles of planning and mode-choice decision-making in Brisbane's transport networks, Australian Planner, 52:3, 229-240, DOI: 10.1080/07293682.2015.1047873 


\title{
Why busways? Styles of planning and mode-choice decision-making in Brisbane's transport networks
}

Michael Tanko* and Matthew Burke

Urban Research Program, Griffith University, Brisbane, Australia

\begin{abstract}
Why did Brisbane build busways? And what does the city's experience reveal about mode-choice decision-making and transport planning in Australian cities? This paper reports on the processes and decisions taken to introduce bus rapid transit (BRT) in Brisbane in the 1990s with specific focus on the styles of planning involved. Using theoretical frameworks provided by Innes and Gruber, Forester, and other planning theorists, different planning styles are identified. These concepts are used and tested in the case of the South East Busway, Brisbane's first and very successful introduction of BRT. The research involved archival reviews of reports, plans and media articles showing the development and adoption of busways in Brisbane, and interviews with politicians, state and local government bureaucrats and consultants involved in the decision as well as a key independent observer who was critical of the project and its planning. The results suggest that Brisbane may never have adopted BRT without a clear political champion in Brisbane City Council, who intuitively adopted BRT as a 'solution' for Brisbane and who directed a strong bureaucratic effort to co-opt and win support from others including the then state transport minister. Technical- rational analyses were used only to help support pre-determined positions, not to provide mode comparison and assessment for a later mode selection decision. There was no real community social movement supporting the move, and negligible collaborative planning involved. The results highlight how during recent decades planners have shifted away from traditional technical/analytical roles to become facilitators of politically motivated decisions in the transport decision-making process, and the risks and benefits this provides.
\end{abstract}

Keywords: Bus rapid transit; planning styles; transport planning; mode selection; Brisbane

\section{Introduction}

Transport planning in Australian cities continues to be shaped by institutional, political and professional imperatives. Transport planning is defined by the Planning Institute of Australia (2012) as 'concerned with identifying and planning for the accessibility needs of people and freight within liveable and sustainable communities' including the planning for and delivery of different transport modes, and including both infrastructure and services. Transport planning is in part about determining how we spend money on transport infrastructure with an aim to secure the best solution possible, within the availability of resources available (Black 1981). The UK's Transport Planning Society (2013) state that transport planners are critical in identifying how transport systems can be improved to stimulate and support economic growth and that they 'take a lead in planning and designing for the movement needs of individuals and for the transport of goods, as well as managing transport demand to support economic and environmental efficiency'.

The focus of this paper is on the 'styles' of planning that are evident in urban transport planning in Australia, including the approach, behaviours, and activities of planners. These styles of planning become most pronounced in contested decision-making areas such as the selection of a particular mode for a new public transport facility. We focus in this paper on the case of Brisbane's busways, which introduced a new modal technology into a major Australian city, as a means to better explore how modechoice decisions are made in the Australian context and what this informs about contemporary transport planning practice.

The paper is organised as follows: first, the Brisbane case is outlined to help set out key questions about how transport planning is conceived and practised in contemporary Australia. The literature on the changing practices

*Corresponding author. Email: m.tanko@griffithuni.edu.au 
and the styles of planning used in transport planning is briefly summarised. The methods of the investigation are then provided, followed by the results, which focus mostly on the reflections of a set of key actors involved in the busway introduction. The discussion that follows seeks to draw the findings back to the literature, identifying implications for transport planning policy and practice.

\section{The shifting sands and 'styles' of transport planning}

The more integrative conceptions of planning in recent decades have inveigled transport and infrastructure planning and programs within broader 'spatial planning' activities, focused more on space (Ferreira, Sykes, and Batey 2009, 30). Transport planning practice has therefore shifted significantly in its activities and approaches, although perhaps not always its philosophical leanings. Transport planning has possibly been the most resistant of the fields of planning practice to the Kantian/Habermasian ideas of post- or anti-realism that have helped shape much planning theory and practice in recent decades (Harrison 2014, 67). Perhaps this is partly explained by: the profession's focus on analysis of vehicle, good and trip movements; the positioning of trained engineers in planning roles; and the situating of transport planning within infrastructure agencies and their capital works programs, all of which encourage positivist perspectives. There has been much written of the shifts in planning from both the more positivist and car-oriented paradigms of the past to the more defendable and sustainable paradigms of the present (i.e. Banister 2008).
There is great global cross-fertilization in transport planning practice, particularly due to the role of inter-city and international exchange. As noted by LagendijkandBoertjes $(2013,291)$ cities and regions tend to face similarchallenges and this provides 'a rich seedbed of experience', all of which is accessed through visitors, conferences, fieldtrips, and the like. New transport technologies and design 'solutions', such as variants of transit-oriented development (TOD), as well as key planning approaches and practices, are amongst the many ideas traded in these 'webs of exchange' (291) as planners reflexively respond to local planning challenges. The overseas planning fieldtrip remains one of the great participatory rituals of professional practice, providing opportunities for planners to listen and learn about planning processes, interventions, and their fates in other locales (Forester 1999, 2013, 9).

But there has been little exploration of how the approaches, activities, and behaviours of transport planners in daily practice, or what we may describe as their 'styles' of planning, have changed. Innes and Gruber (2005) and Sager (2009b) have both provided conceptual frameworks that help describe 'styles' of planning. These look at how planners see their work, how they approach it, and what activities they do. Synthesising their approaches one can identify: (1) a technical-rationalist style based on analysis (the planners as expert); (2) a political champion style (where planners act to support the dictates of strong political leaders, or play a political and advocacy role themselves); (3) a social movement style (the planner as activist and/or radical); and (4) a collaborative style (the planner as facilitator and mediator) (see Figure 1). Other styles certainly exist and the

\section{Four Styles of Planning}

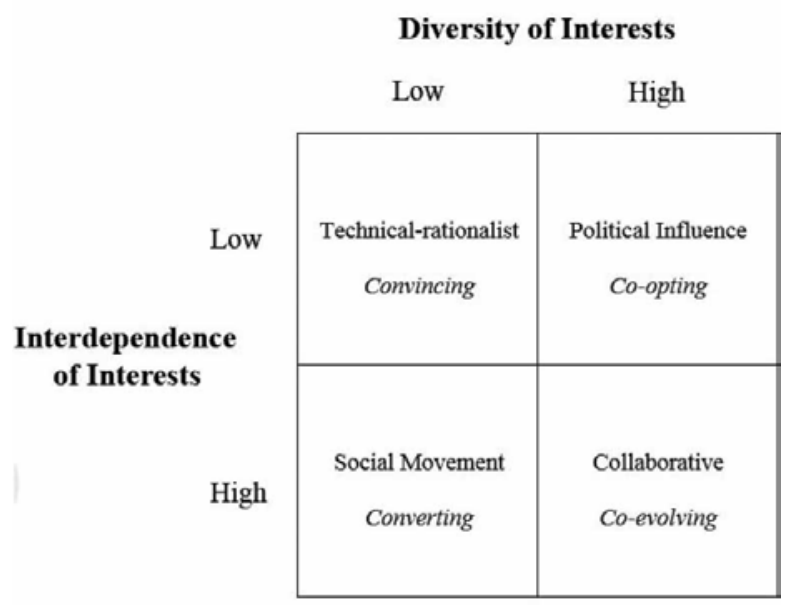

Figure 1. Four styles of planning: the conditions for their use and their theories of change.

Source: Adapted from Innes and Gruber (2005). 
literature is replete with minor variations and additions to these themes (see Forester 1999; Innes and Gruber 2005; Sager 2009a for more). But the four approaches in Figure 1 conceptually represent much of the activity that may be observed in the transport planning field.

Transport planning has generally held to the technicalrationalist style, particularly given the field's focus on modelling, simulation, and evaluation. This approach underpins the significant technical analysis used to support many mode-choice decisions for transport projects in the Australian context, where planners (theoretically) use mostly empirical approaches to analyse and help choose the best option. For instance, projects such as the Gold Coast Light Rail feasibility study have used a multicriteria assessment process with detailed technical analyses to assess mode options, and to systematically weigh variables against set criteria (Gold Coast City Council 2011). When using such technical approaches, the planner is often viewed as a 'value-neutral-analyst' providing advice to political decision-makers, detached from politics (Ozawa and Seltzer 1999, 258). The (ir) rationality this approach implies has been subject to strong critique by planning theorists such as Friedmann (1998), Healey (1997) and Forester (1999). Planners, it has been argued need to be more aware of the cultural and social implications of their decisions, and less detached from the planning process as a whole. They also need to be aware of the contribution of their own sub- jective influence on the planning process, particularly their internal biases. One much-observed bias is the way in which transport planners often inherently favour one mode or another, particularly in the contested spheres of road versus public transport, or bus versus rail investments (i.e. see Lagendijk and Boertjes 2013, 295). Both Vuchic (1999) and Mees $(2000,82,2010,165)$ are dismissive of technology enthusiast planners and advocates, suggesting in ideal planning processes transport planners should be unbiased in their choice of modes and, as is rarely the case, looking first and foremost at non-engineering solutions. Despite such advice a major trend in Australian planning has been the 'infrastructure turn', which has resulted in infrastructure projects becoming a primary mode of intervention in addressing urban problems (Dodson 2009). Where Stone and Mees (2010) have looked towards reorganisation of public transport networks and use of existing assets as a way forward, most cities have instead pursued major infrastructure 'solutions' to manage travel demands. What impacts the infrastructure turn has had on the styles of planning amongst professionals is a question worth posing.

\section{Busway research}

Brisbane's busways are a form of bus rapid transit (BRT) and are an example of international technology transfer.
Essentially, BRT comprises high capacity buses that are prioritised on purpose-designed roads, with stations at widely spaced stopping distances and distinct branding, which in effect mimic the operation of light rail transit (LRT) systems (Hoffman 2008, xi). In the case of busways, a BRT will operate exclusively in its own rightof-way. Brisbane's busways conform to what Hoffman (2008, 1-2) describes as the 'Quickway' model of BRT, with high-speed rights-of-way that provide for a range of routes, many of which bypass some stations in passing lanes, and which branch off to service locations outside the alignment of the busway itself. This offers minimal travel times and high-volume operations. The Quickway model has its own distinct planning and service logic allowing for a dense network of routes that service a wide sector of a city to coalesce into a single corridor. The Brisbane busways have been praised for their best practice design by key international experts (Levinson et al. 2003). A map of the existing Brisbane busway network and proposed future extensions is provided in Figure 2.

Research into BRT has expanded greatly in the last three decades, including in Australia (i.e. see Ardila and Rodriguez 2001; Currie and Delbosc 2010; Gardner and Fouracre 1990; Hensher 1999; Hoffman 2008). BRT systems in Australia expanded by $200 \%$ or some 216 route kilometres between 2006 and 2010, with patronage of 86 million passengers per annum in 2010 (Currie and Delbosc 2010, 305). But there has constantly been a debate about the relative merits of BRT as opposed to LRT, and there remain research questions about the relative cost-effectiveness of busways of the Quickway design that are outstanding. Examples of these questions include the comparative cost of providing Quickway corridors versus other modes, and whether they are cost effective from a passenger-carrying perspective.

Another key research gap is in terms of how new systems such as busways are first considered by planners and decision-makers, and secondly, how they progress from concept to plan to investment decision, to construction and the planning processes that occur along the way. The most pertinent study in this area has been the work of Pulichino and Coughlin (2005) who explored the way in which political decision-makers and planners have gone about providing preferential treatment for buses, defined as anything from signal priority through to installing busways. Drawing on research on eleven cities in Europe and North America they found that technical and financial analysis has consistently shown bus investment to be preferable to LRT or highways. Benchmarking studies by planners and international visits were often critical in influencing policy makers to make bus-based investment decisions (Pulichino and Coughlin 2005, 84). And whilst famous BRT cities such as Curitiba and Bogota had political champions ('policy entrepreneurs') who emerged and implemented systems from above 


\section{TransLink busway network}

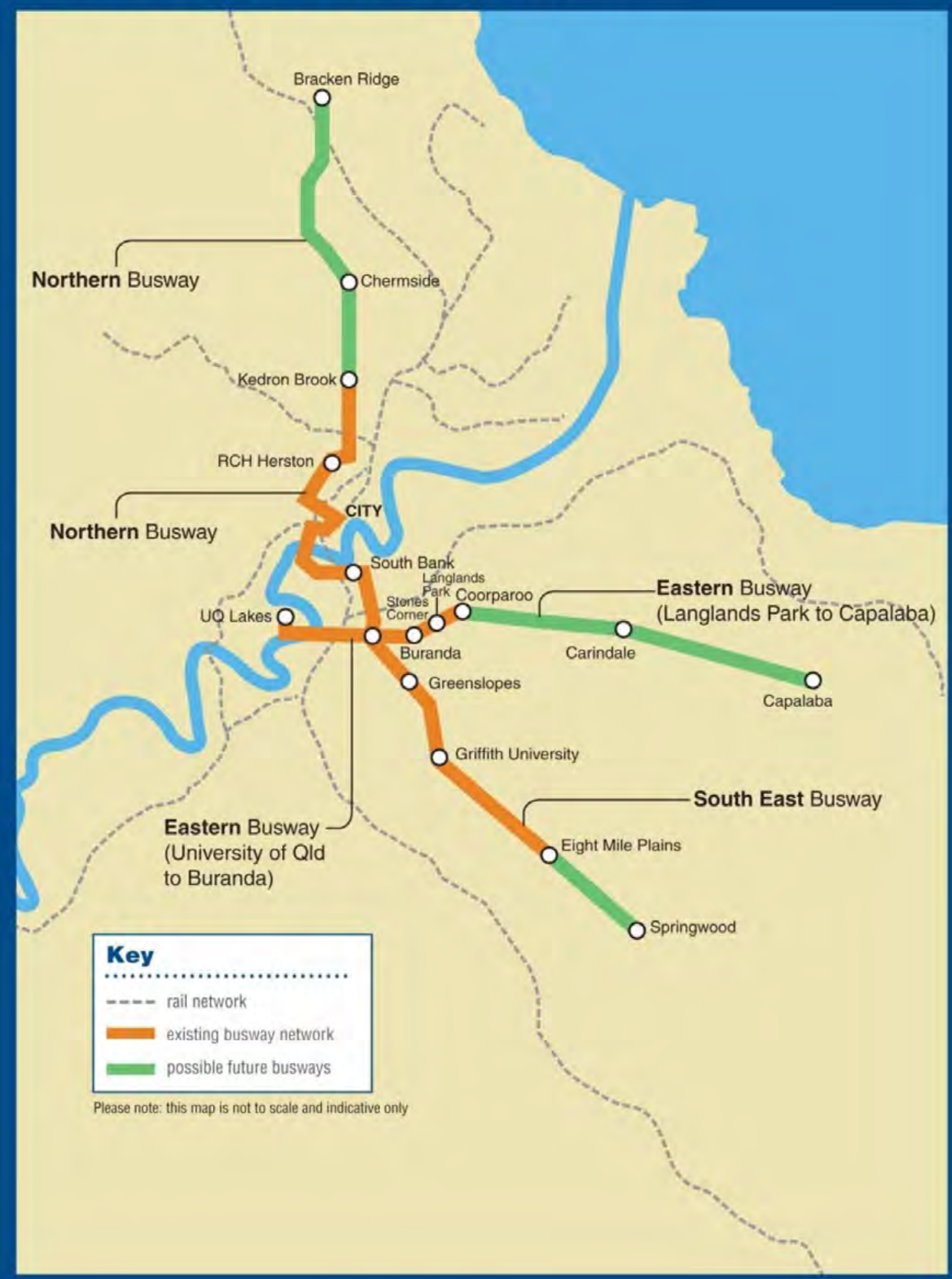

Figure 2. Brisbane's busway network and proposed extensions.

Source: Translink (2014) used with permission. 
with little technical or consensual decision-making processes, cities such as Ottawa had seemingly arrived at BRT more by consensus and technical appraisal (Pulichino and Coughlin 2005, 85). These differences suggest context-specific transport planning cultures, with concurrent shifts in the role of planners and their activities. We sought to determine what occurred in the decisions to implement BRT in the largest Australian rollout in Brisbane, and what this informs about Austra- lian transport planning practice.

\section{Approach and method}

The research used an archival review of documents relating to the early development of the Brisbane busways and a set of interviews with key personnel directly involved in the South East Busway project, which first introduced BRT to Brisbane. Participants were selected for their involvement in the BRT mode decision-making process. This included the two key local government bureaucrats involved, a key state government bureaucrat, a number of influential private consultants and a leading academic/independent observer who was never part of the project teams but who had observed the planning processes at work. These participants are de-identified and their previous roles outlined in Table 1 . Interviews were in the form of semi-structured interviews, with a focus on allowing respondents to tell their complete story of the busway's development from their own perspective. Interviews were conducted either in person or by telephone, with in some cases answers to questions provided in writing at the participant's request. The interviews were partially transcribed and these transcripts explored using thematic analysis. For more on the methods used for these interviews see Tanko (2013, 34-38).

We present the results in a narrative format, mostly in chronological order, given this was how many of the interviewees related their knowledge of the busways and their planning. We focus in this paper on the planning activities, styles of planning involved and the respondent's views, but it is necessary to understand the prior context to make sense of the material.

\section{Context}

It is somewhat surprising that Brisbane invested so heavily in fully separated busways given the city's historical legacy of an extensive commuter rail network of over $200 \mathrm{~km}$, focused on the central business district (CBD). The city also once had an extensive streetcar network work that was municipalised (taken over by the Brisbane City Council (BCC)) in the 1920s and replaced by bus operations in the 1960s. This left the city in the mid1990s with a state government rail operator and, within the very large Brisbane City boundaries, a single powerful local government bus operator in Brisbane Transport, which is fully owned and managed by BCC (Cole 1984). The two public transport systems were mostly operated as distinct, segregated networks. Only at few locations did buses interchange with trains, standardised multi-modal ticketing had yet to be introduced, and as few as $9 \%$ of train patrons arrived at stations by bus (Mees 1997). Many bus services paralleled train lines (and still do) creating competition for patronage. Investment in the rail and bus networks was relatively modest in the post- war era, as the focus of investment was put into develop- ing freeway networks in line with the recommendations of the 1965 Brisbane Transportation Study (Wilbur Smith and Associates 1965).

The first of two road revolts with electoral consequences then shifted the trajectory of transport planning in the city. In 1991, Jim Soorley was elected Lord Mayor of Brisbane City, in part thanks to an anti-roads platform against a motorway link proposed for the inner-Northern suburbs. Soon after in 1995, the state Labor government was unseated in part due to the unpo- pularity of key arterial and freeway proposals, including the South Coast Motorway which was to run parallel to the east of the existing Pacific Motorway to the Gold Coast through koala habitat (Krosch 2010, 21-22). As such, the new regimes in both state and local government were reticent to build roads or preserve corridors. They commenced a new approach of 'balanced' transport plan- ning, which many cities had been through in the 1960s (see Mees 2000,73 ) where the overwhelming proportion of capital investment given to roads was reduced

Table 1. Interview participants.

\begin{tabular}{|c|c|}
\hline Participant & Role and involvement \\
\hline Local Councillor (LC1) & Former head of Brisbane Transport for BCC \\
\hline Local Council Employee (LC2) & A former divisional manager of transport for $\mathrm{BCC}$ \\
\hline State Government Employee (SGE1) & A senior manager in the former Qld Department of Transport involved in the busway programs \\
\hline Private Consultant (PC1) & A key private consultant involved in the busway projects in Brisbane \\
\hline Private Consultant (PC2) & A consultant who contributed to the preliminary Brisbane Busway Plan \\
\hline Private Consultant (PC3) & A former project director for the planning of the busway network \\
\hline Transport Academic (TA1) & Advisor to a key Parliamentary Committee examining the South East Busway Project \\
\hline
\end{tabular}


somewhat and more provided instead to public transport and, to much lesser degree, cycling. It was within this milieu that the busway concept first developed.

\section{When and where did the busway concept emerge?}

The interviewees were unanimous that busways were first put on the agenda around 1994, prior to the fall of the Labor state government. The lead was taken by $\mathrm{Cr}$ Maureen Hayes of BCC, who was then Chair of Traffic and Transport. This is in contrast to Mees' (2010, 120121) assertions that Soorley was the main actor. Cr Hayes was at the time exploring with the Lord Mayor and council officers options for improving travel times and lessening congestion effects on the Brisbane Transport bus fleet. The head of Hornibrook Buslines, who run buses in nearby Redcliffe, had recently visited Ottawa's busway system and encouraged her to visit that city as a side-trip to a transport conference the Coun- cillor was attending in Boston. Cr Hayes, seemingly impressed by what the delegation saw in Ottawa, com- missioned the mostly engineering consultants McCor- mick Rankin to produce a preliminary report on the concept in 1995 (McCormick Rankin 1995). This mainly conceptual infrastructure-based plan proposed busway corridors running north, south, east, and west of Brisbane's city centre, as shown in Figure 3.

Reviewing the report one finds few figures, negligible evaluation and very little technical analysis. The rail network is almost completely ignored, and especially options to encourage interchange. Consistent with the 'infrastructure turn' the focus is on a big build to solve the city's problems. Key interviewees report that at this stage the technical work that was happening behind the scenes in BCC was limited to estimations of future trans- port demands and movement patterns in the city, along with considerations of how to stage possible busways, and tentative funding options. The Council Chair of Transport began to promote and advocate for the propo- sal. But only limited consultation with other stakeholders occurred at this earliest phase. Some interviewees suggest there grew significant belief in the concept within BCC and amongst the consultants involved, as well as its possible public acceptance:

If it could be shown to be fast and efficient like Ottawa, the Busway and public transport in general would be accepted. (PC1, 2013)

In state government, however, there was significant resistance to the proposal, particularly in the key transport department. The interviewees did not suggest why there was resistance at first, other than one who noted '... maybe because they hadn't thought of it' (SGE1, 2012). The most logical corridor for the busway was a state government road within the South East Freeway's reserved land. As such it needed the support of Queensland's Transport Minister and his department, and their coming around to BCC's view. But there was a mechanism by which to have the discussion in that a South East Queensland Transit Authority (SEQTA) had been established, which forced some level of cooperation between BCC and the Goss Labor government, but may not institutionally have supported the busway concept.

The 1995 State Election, which was so heavily influenced by the South Coast Motorway protest, helped change the game. The Goss Labor government clung to power for some months until the Mundingburra by-election. During that time, to meet the growing traffic demand in the city's southern corridor, while abandoning the unpopular South Coast Motorway proposal, the department proposed widening the Pacific Motorway and South East Freeway corridor to eight lanes of general traffic. However, the section within Brisbane City's boundaries, along the SE Freeway, which runs some $15 \mathrm{~km}$ to the edge of the CBD, was to be widened for either bus lanes or a busway, even though no-one quite knew what the latter would look like, and there had been no technical appraisal:

The configuration at this time wasn't known - whether it was going to be simply bus lanes, or as it turned out, a fully segregated bus highway. (SGE1, 2013)

After the installation of a National/Liberal coalition government, Vaughan Johnston, a rural National Party member, became Minister for Transport. He abolished the SEQTA, which might have proved problematic for the busway proposal, as that agency may have assisted in the coordination of plans between government depart- ments. But he also established a new process of 'inte- grated regional transport planning' (IRTP) that sought to better service public transport. It was a process that cul- minated later in the 1997 Integrated Regional Transport Plan (Queensland Transport 1996); a typical 'balanced' transport plan of the period. The team working on the IRTP adopted mode share targets to reduce future car use and promote public transport. Inserted somewhat clumsily into the 1996 draft was a clear proposal to include busways, despite, still, there not being any significant technical appraisal. The IRTP took the original BCC proposal and expanded it, promoting an 'SEQ Regional Busway System' growing into $75 \mathrm{~km}$ of dedicated busways and around 65 stations (Queensland Transport 1996, 35). Unlike the rail system, which had minimal networking with the surrounding suburban bus services, feeder buses were proposed to serve the busway then continue along it to the CBD (Figure 4).

The inclusion of busways, to such a degree, in part relates to problems of rail planning and management at 


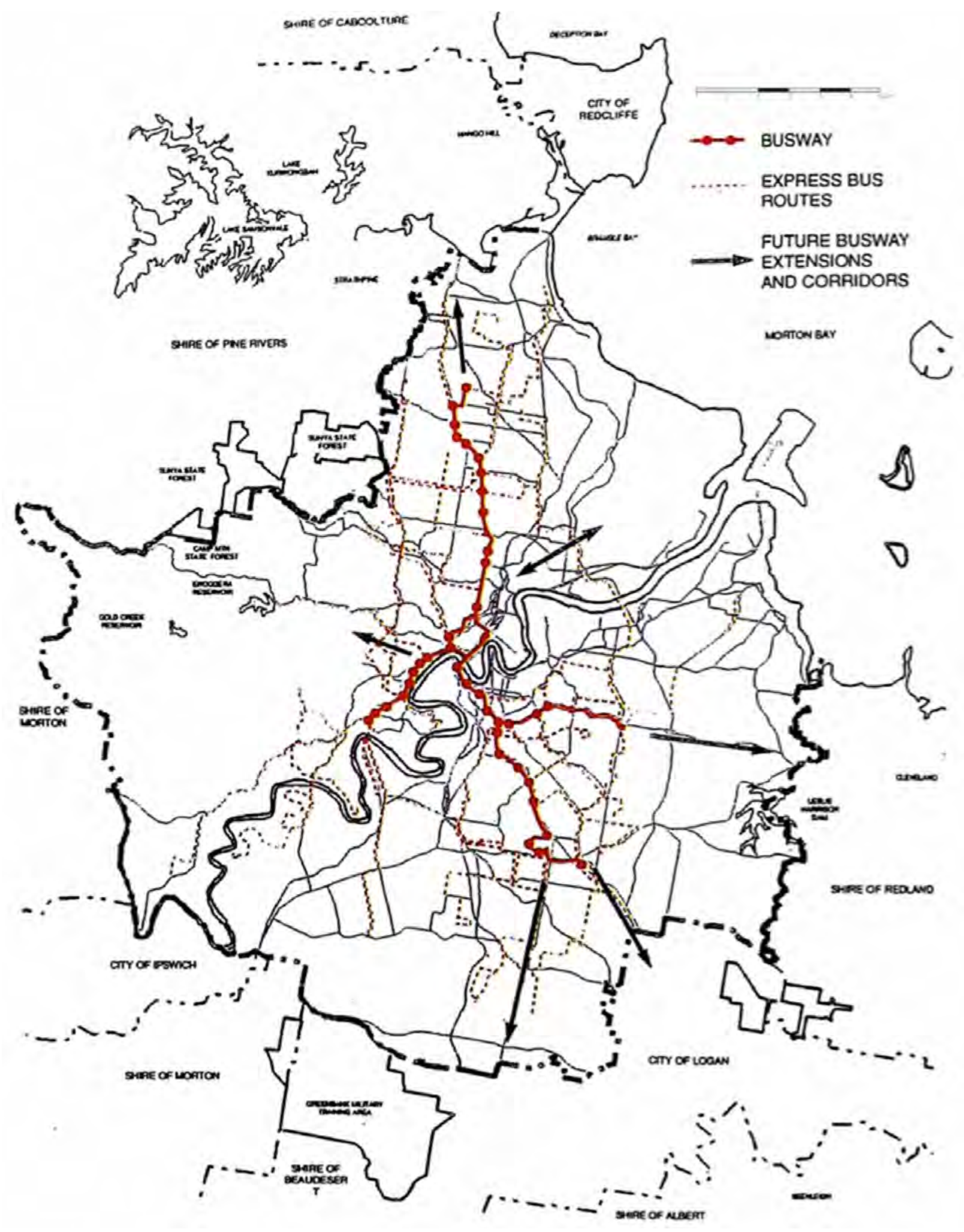

Figure 3. Conceptual busway network proposal.

Source: McCormick Rankin (1995) used with permission. 


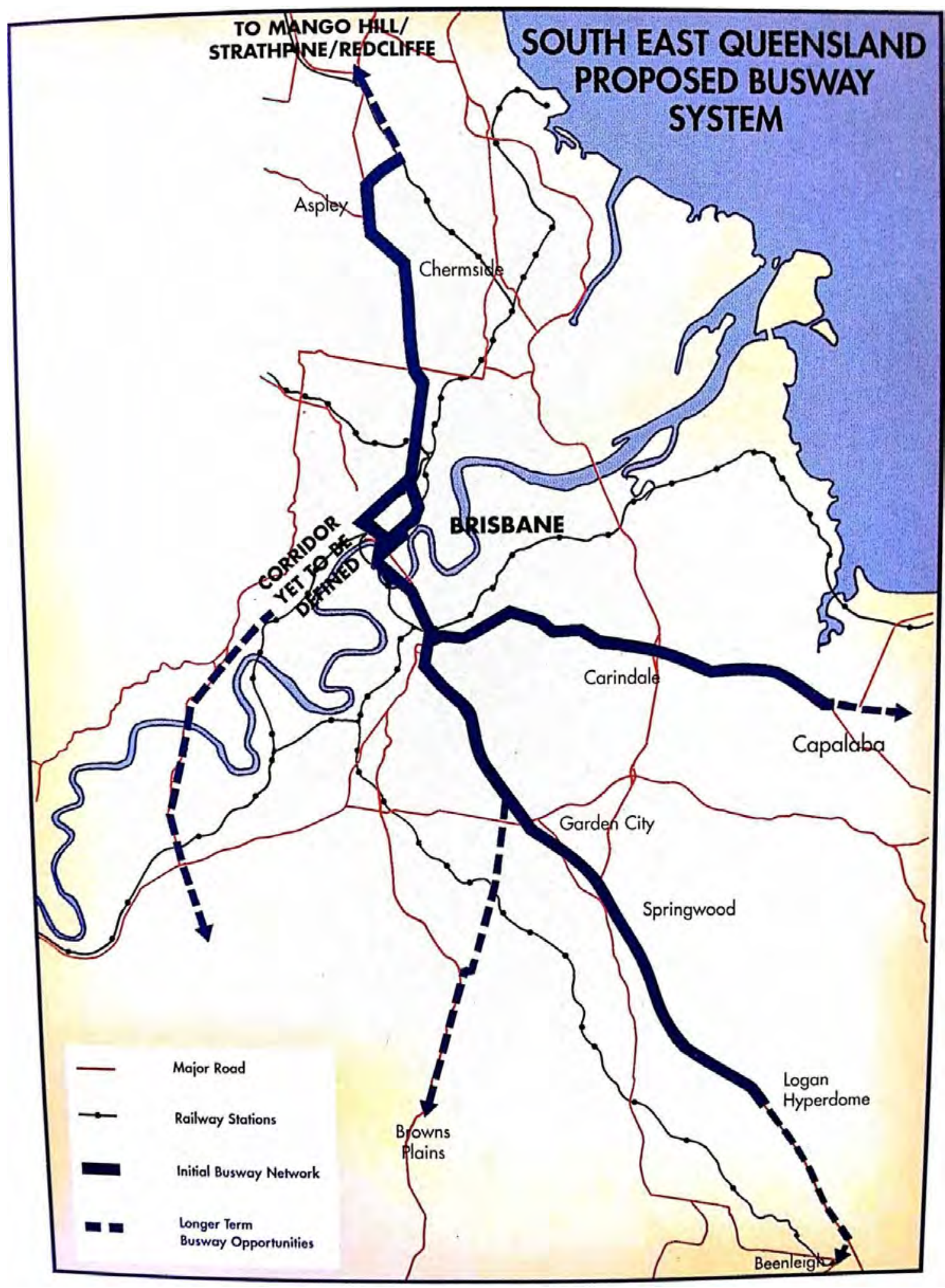

Figure 4. The 'SEQ Regional Busway System' proposed in the 1996 Draft ITRP.

Source: Queensland Transport $(1996,37)$ used with permission. This map is not to scale and indicative only. 
the time perceived by the interviewees, and either the lack of capacity or willingness of Queensland Rail to be proactive. The 'reason Busways were in the plan was because we couldn't do any rail planning' and that 'No one except the planning team was behind it (improving rail)' (SGE1).

Only cursory analysis of an LRT option for the corridor was considered, but dismissed relatively quickly, one interviewee noting that 'at the end of the day, it was determined to be very costly and disruptive to traffic where it

would run at grade on the existing roadways' (PC3, 2013). LRT would also have required passengers to interchange, which was broadly seen as undesirable and not part of the local public transport culture at that time.

By early 1996 two options seemed possible. Widening the South East Freeway for general traffic and/or bus lanes or the option of a fully segregated busway. No noninfrastructure 'solution' had been envisaged. The planners involved in the state and local bureaucracies both took on an advocacy role at this point, using limited empirical facts, and seeking to persuade the Minister and his office that the busway option was preferable. Officers from the IRTP planning team and others made it clear to the Minister that though a busway could eventually carry 18,000 people an hour across both lanes, a general traffic lane may only add capacity for around 1,500. Importantly, the planners used the (then) new technology of presentation slideshows creatively to allow the decision- makers to envision the system, to understand its potential, and win their support. The Transport Minister soon became an advocate for the system himself.

Even though they were on different sides of politics Maureen Hayes and Vaughan Johnson were in agreeance and were political champions for the Busway. (PC1 1, 2012)

The lack of Commonwealth funding availability for public transport, under Australia's Howard Government, meant only state cabinet needed convincing. Despite the planner's and key politicians efforts and growing bipartisan support, one of our informants suggested it took three separate cabinet submissions to get the SE Busway signed off by the Queensland Government. Perhaps this was due to the lack of a sound technical case, of the type commonly used for justifying most major transport investments. No convincing cost-benefit analysis, based on extensive patronage forecasting was ever seemingly produced.

Once committed to, the South East Busway project swiftly moved into the consultation, design, and construction stages. A director was appointed to manage the project who 'didn't know what a Busway station looked like' (PC1, 2013) but the design and construction team involved did perform, undeniably in hindsight, a stellar job in a short time frame. Around ten studies were commissioned on issues such as lane widths, station design standards, station locations and surrounding land-use policies. An impact management plan followed, with the public consultation proceeding in 1997. The issue of rezoning land uses around the busway stations to generate TOD was shelved, however, until after construction, which was to prove a very significant planning error. No consultation with the community on firm proposals for rezoning to allow medium density or mix uses near busway stations in suburban locations was conducted. Residents in low-density neighbourhoods were simply provided a busway station.

An expedited section between the city and Woolloongabba was first opened as a shuttle service in August 2000 in time for the 2000 Olympic Games for events held at the Gabba sporting stadium. The full $16.5 \mathrm{~km}$ SE Busway from Brisbane CBD to Eight Mile Plains opened in October 2000 (Figure 5). This busway has been a patronage success with an evaluation by Bitzios (2009) finding it carried 12,400 passengers per hour one-way in peak periods by 2007-2008, with travel time savings of over $\$ 130$ million per annum, albeit with a relatively low benefit-cost ratio being estimated for the project as a whole.

In the years immediately after opening, an attempt was made to rezone the area around Holland Park busway station, some $8 \mathrm{~km}$ from the city centre, to create a small TOD. But this attempt met with fierce local community opposition from households who had received the benefits of the busway station but did not wish to give up any of their perceived local amenity. No rezoning has yet occurred. In addition, the lack of investment in rail capacity has now caught up with Bris- bane, with the city today confronted by a crisis if it cannot provide additional cross-river capacity in the near future, for which no Commonwealth funding has been made available (see Ironside 2013).

\section{Participant reflections on the planning process}

Reflecting on the transport planning processes used, the informants were clear that the technical analysis was often only employed to back up the gut feeling of a political champion such as BCC's Traffic and Transport Chair, and other senior decision-makers, after key decisions had been taken. One informant succinctly described the planning process as 'ex-post facto rationalisation on a decision already made' (TA1, 2012). This brings to light the deficiencies of a planning process when there really was no overt planning theory or method implemented and where infrastructure and engin- eering options pre-dominate. This asks questions about the validity of current approaches to transport planning theory and education if there is such a mismatch with actual practice. The 'enormous battery of transport investment evaluatory techniques' that has long been available 


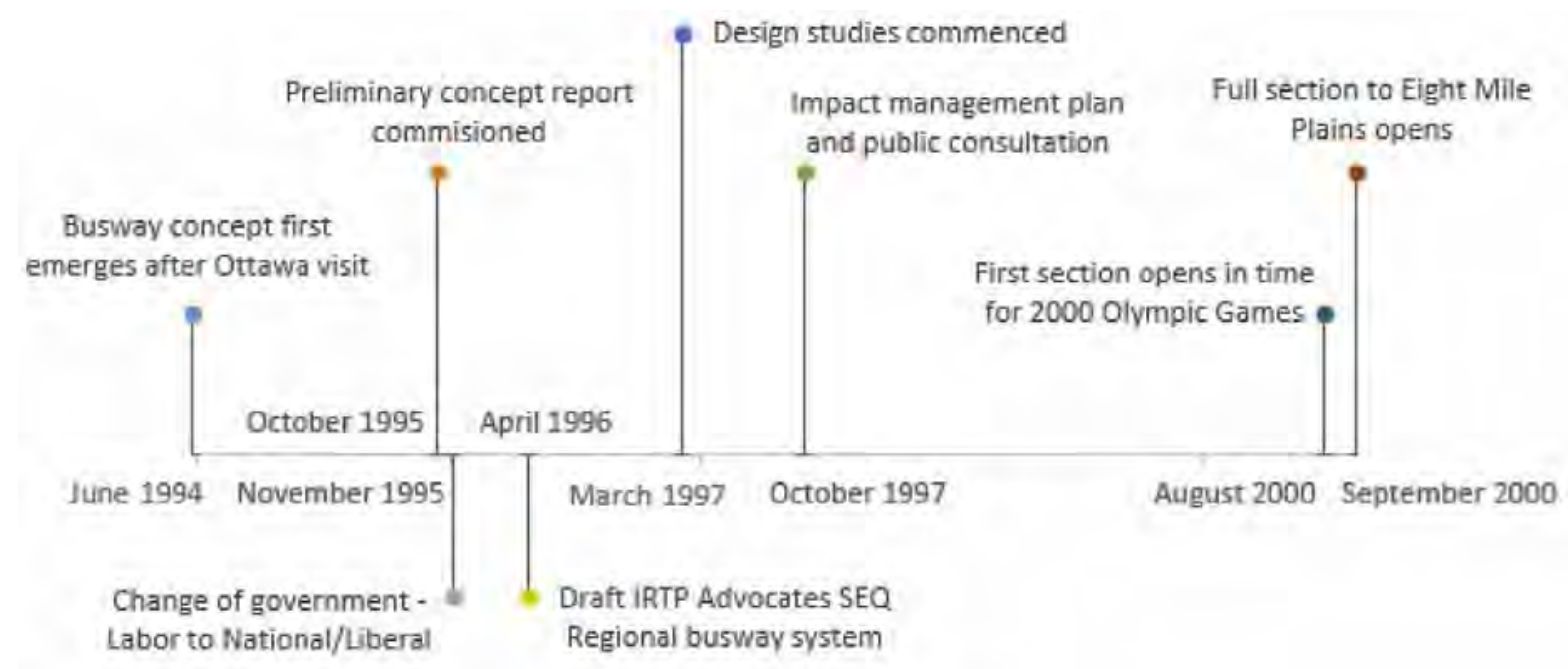

Figure 5. Timeline of events in the busway development.

to transport planners (Truelove 1992, 4) was not harnessed to compare the BRT option meaningfully with LRT, nor a bus-rail interchange plan that would have made better use of the existing large CityRail network.

Reflecting on this, one of the state government officials suggested 'I think it's very rare that the technician gets to make the best transport policy decisions' (SGE1). This was a theme that many of the engineer/plan- ners repeated in their interviews, suggesting they had preferences for more technical-rational planning activity, or at least for a style that used a combination of significant technical assessment within the overall framework. This technical role of transport planners remains important to them, and they see it as also important to the outcomes produced by their work. They also felt that the voice of the technician was an important one in the debate, to justify a project. One participant noted, political championing was 'certainly' influential in the busway planning process, but some technical proficiency was still required:

no politician can stand alone without the support and backing of the technical experts i.e. the transportation planners, civil engineers, the urban and community planners along with a plethora of other experts such as architects, communication experts and project managers. (PC3, 2013)

The short time frame of the planning process was also identified as an issue. Whilst most of the participants were satisfied with the busway outcome, some mused about the problems the city now faced in terms of passenger rail operations and felt that more should have been done earlier in planning and investing in new rail capacity. One also noted the lack of TOD planning which had led to a less than ideal land-use arrangement to support the busway.

\section{Discussion}

The personal accounts provided in this study show how important having political champions were to Brisbane building busways. The research found that as opposed to the traditional analytical role of the transport planner, there was a distinct lack of technical-rational analysis in the key busway mode-choice decision. Planners' roles were quite different, either supporting BCC's position, as advocated by Council's Traffic and Transport Chair, or providing limited technical and bureaucratic support for the busway option to help BCC co-opt first the rel- evant state government department and then the Transport Minister towards their vision, including through a change of government. The planners helped support and facilitate the deal-making, and participated in those deals as advocates, rather than being analysts providing a technical case for the busway scheme.

The Brisbane case shows that transport planners are taking on a greater variety of planning styles, with their capacity to engage in political, policy, and advocacy spheres. Even trained engineers took on a more facilitating role. Brisbane sits more alongside Curitiba and Bogota as a city that invested in BRT on the basis of the gut feel and drive of political champions/entrepreneurs than it did technical expertise and analysis (Puli-

chino and Coughlin 2005). Interestingly all three of these cities have been cited by Hoffman (2008) in his key international review as successful busway innovators.

The study highlights that many decision-makers tend to make decisions intuitively, often aided by a first-hand or visual experience. It was after the participatory ritual of a fieldtrip to Ottawa that the Traffic and Transport Chair at BCC made an instinctive decision to commission a report for a Brisbane BRT plan. And it was only after a 
visual presentation that the Transport Minister was won over to the busway option. The 'infrastructure turn' in Australian planning (Dodson 2009) appears in part powered by the visual seduction of big things. More intellectually demanding but cheaper non-infrastructure options, such as public transport network planning, remain difficult to communicate and to promote to communities. The study also highlights how transport and land-use decisions should be taken together. The case of the aborted Holland Park West station rezoning suggests if planners do not consult with communities and get agreement on TOD proposals ahead of public transport construction, then they may never achieve preferred transport/land-use arrangements. Doing planning holistically is much better than taking the path-of-least resistance.

The major findings of this study indicate that transport planning depends heavily on political influence and cooption in the development of many major projects. Technical analysis does not contribute as significantly as it once did during the time of the major freeway expansions in Australian cities. As a result planners must now learn to work in other ways within the political framework, as it has been shown that this is critical in mode-choice decisions in transport planning.

There are a number of risks and benefits that arise from this shift to transport planners being more facilitators and less technicians and experts. Forester (1999) argues how planners in this context are in the position to facilitate greater participatory process to achieve greater end results that are more reflective of the desires of the community and other stakeholders, both in govern- ment and private consultancies. Benefits in this specific study include more potential for innovation, more rapid response, and of course better community and stakeholder involvement and ownership. This is especially true for unconventional and untested plans where no precedent currently exists. It offers prospects for innovative transport plans to have a hearing and be actively considered by stakeholders. What such innovative plans exactly will look like is uncertain, and that is part of the allure, although it can be reasoned that they will involve greater creativity than is currently available in conven- tional transport planning options.

Planner's presentation skills and networking were seen as especially important in the Brisbane case, and the profession is well suited to such advocacy activities. However, just as easily, the subsuming of the technical role creates potential for poor ideas to take root and be promoted, with perhaps disastrous and costly results. Not always will political policy entrepreneurs get it right. Some recent Spanish light rail projects, which never appeared in planning documents but were promised by Mayors and built in rapid time, have collapsed and ceased operations, due to lack of patronage immediately after opening, costing cash-strapped authorities millions (see Carpintero and Petersen 2014). Technical analysis can help this situation, and when used appropriately, and presented to political decision-makers effectively can avoid such debacles and increase the possibility of a rational and effective solution being implemented. Then again, technical analysis myopically focused on road congestion by engineers has tended over the years to identify primarily road-augmentation 'solutions' rather than options involving other modes or policy measures, and one needs to do the right forms of analysis.

The limitations of this study include the focus on only one case in one Australian city, and this work should be expanded to consider other transport projects to gain a richer understanding of the planning styles being used by transport planners today, including in other jurisdictions, in areas such as freight planning and in situations where planners have helped underpin much longer gestations for transport projects such as the Gold Coast light rail scheme. Research is also needed into how decision-makers view planning within the transport

field, and how best to communicate ideas such as new technological solutions to them. These are avenues for further research.

\section{Acknowledgements}

The authors wish to thank interview participants for their valuable contribution, as well as McCormick Rankin Corporation, Translink and the Queensland Government for kindly allowing reproduction of archival materials.

\section{References}

Ardila, A., and D. A. Rodriguez. 2001. "How Chaos Does Not Destroy Ridership: Operations of an Exclusive Busway Carrying More Than 35,000 Passengers Per Hour Per Direction." Transportation Research Record: Journal of the Transportation Research Board 1726: 1-7.

Banister, D. 2008. "The Sustainable Mobility Paradigm." Transport Policy 15 (2): 73-80.

Bitzios, D. 2009. "Measuring Benefits of the South-East Busway: Towards a New Approach for Valuing Public Transport Projects." Proceedings of the 2009 Australasian Transport Research Forum, Auckland, NZ, September 29October 1.

Black, J. 1981. Urban Transport Planning: Theory and Practice. London: Croom Helm.

Carpintero, S., and O. H. Petersen. 2014. "PPP Projects in Transport: Evidence from Light Rail Projects in Spain." Public Money \& Management 34 (1): 43-50.

Cole, J. 1984. Shaping a City: Greater Brisbane 1925-1985. Eagle Farm, QLD: William Brooks.

Currie, G., and A. Delbosc. 2010. "Bus Rapid Transit in Australasia An Update on Progress." Built Environment 36 (3): $328-343$ 
Dodson, J. 2009. “The 'Infrastructure Turn' in Australian Metropolitan Spatial Planning." International Planning Studies 14 (2): 109-123.

Ferreira, A., Sykes, O., and P. Batey. 2009. "Planning Theory or Planning Theories? The Hydra Model and Its Implications for Planning Education." Journal for Education in the Built Environment 4 (2): 29-54.

Forester, J. 1999. The Deliberative Practitioner: Encouraging Participatory Planning Processes. Cambridge: MIT Press. Forester, J. 2013. "On the Theory and Practice of Critical Pragmatism: Deliberative Practice and Creative Negotiations." Planning Theory 12 (1): 5-22.

Friedmann, J. 1998. "The New Political Economy of Planning: The Rise of Civil Society." In Cities for Citizens: Planning and the Rise of Civil Society in a Global Age, edited by Mike Douglass and John Friedmann, 19-35. London: John Wiley \& Sons.

Gardner, G., and P. Fouracre. 1990. "Busway Transit - The TRRL Study." Presented at European Transport and Planning, 18th summer annual meeting, "Public Transport Planning and Operations", University of Sussex, England, September 10-14.

Gold Coast City Council. 2011. Gold Coast Light Rail Feasibility Study: Summary Report - Draft. Gold Coast, Australia: GCCC.

Harrison, P. 2014. "Making Planning Theory Real." Planning Theory 13 (1): 65-81.

Healey, P. 1997. Collaborative Planning: Shaping Places in Fragmented Societies. Vancouver: UBC Press.

Hensher, D. 1999. "A Bus-Based Transitway or Light Rail? Continuing the Saga on Choice Versus Blind Commitment." Road \& Transport Research 8 (3): 3-20.

Hoffman, A. 2008. Advanced Network Planning for Bus Rapid Transit: The "Quickway" Model as a Modal Alternative to "Light Rail Lite". Washington, DC: Federal Transit Administration, USDOT.

Innes, J. E., and J. Gruber. 2005. "Planning Styles in Conflict: The Metropolitan Transportation Commission." Journal of the American Planning Association 71 (2): 177-188.

Ironside, R. 2013. "Opposition Leader Tony Abbott Backtracks on 2010 Election Promise Taking Brisbane Cross River Rail Off List." Courier Mail, April 5. Brisbane: News Ltd.

Krosch, A. 2010. "History of Brisbane's Major Arterial Roads a Main Roads Perspective: Part 2." Queensland Roads(8): 15-27.

Lagendijk, A., and S. Boertjes. 2013. "Light Rail: All Change Please! A Post-structural Perspective on the Global Mushrooming of a Transport Concept." Planning Theory 12: 290-310.

Levinson, H., S. Zimmerman, J. Clinger, S. Rutherford, R. Smith, J. Cracknell, and R. Soberman. 2003. "Bus Rapid
Transit." In Case Studies in Bus Rapid Transit, edited by Herbert S. Levinson, 23-32. Washington, DC: Transportation Research Board.

McCormick Rankin. 1995. A Busway Strategy for Brisbane City. Brisbane: McCormick Rankin.

Mees, P. 1997. Brisbane Busways: A Report to the Public Works Committee, Parliament of Queensland. Canberra: Urban Research Program, Research School of Social Sciences, Australian National University.

Mees, P. 2000. A Very Public Solution: Transport in the Dispersed City. Carlton South, VIC: Melbourne University Press.

Mees, P. 2010. Transport for Suburbia: Beyond the Automobile Age. London: Earthscan.

Ozawa, C. P., and E. P. Seltzer. 1999. "Taking Our Bearings: Mapping a Relationship among Planning Practice, Theory, and Education." Journal of Planning Education and Research 18 (3): 257-266.

Planning Institute of Australia. 2012. Transport Planning. Canberra: Planning Institute of Australia.

Pulichino, M., and J. Coughlin. 2005. "Introducing Transit Preferential Treatment: Is a Political Maverick Necessary for Public Transportation to Innovate?" Journal of Urban Planning and Development 131 (2): 79-86.

Queensland Transport. 1996. Integrated Regional Transport Plan for South East Queensland: Draft. Brisbane: Queensland Government.

Sager, T. 2009a. "Planners' Role: Torn Between Dialogical Ideals and Neo-liberal Realities." European Planning Studies 17 (1): 65-84.

Sager, T. 2009b. "Responsibilities of Theorists: The Case of Communicative Planning Theory." Progress in Planning 72 (1): $1-51$.

Stone, J., and P. Mees. 2010. "Planning Public Transport Networks in the Post-petroleum Era." Australian Planner 47 (4): 263-271.

Tanko, M. 2013. Planning Styles in Conflict: An Exploration of the Mode Choice Decision in the Brisbane Bus Rapid Transit project. Honours thesis, School of Environment, Griffith University.

Translink. 2014. TransLink Busway Network Map. Brisbane: Queensland Government.

Transport Planning Society. 2013. The Profession. London: TPS.

Truelove, P. 1992. Decision Making in Transport Planning. Harlow, England: Longman Scientific \& Technical.

Vuchic, V. R. 1999. Transportation for Liveable Cities. Ann Arbor: Center for Urban Policy Research (CUPR Press).

Wilbur Smith and Associates. 1965. Brisbane Transportation Study: Summary Report. Brisbane: Queensland Main Roads Department. 